\title{
Acquired melanosis with hypertrichosis and intralesional acne in a 21-year old male patient: A treatment strategy
}

Tirado-Sánchez Andrés, Velazquez María José and Bonifaz Alexandro

Dermatology department, Hospital General de México

\section{Case Report}

A 21-year old male presented with a one-year progressive pigmentation on the left shoulder with hypertrichosis and intralesional acne. He denied associated symptoms or personal and/or family history of similar lesions. A physical examination revealed an irregular brownish hyperchromic patch with hair growth distributed on the left shoulder along with papulopustular eruption with comedones and nodules with predilection at the site of the melanosis (Figure 1).

Clinically a diagnosis of Becker's melanosis with hypertrichosis and acne was performed (Figure 2) A biopsy of the melanosis revealed acanthosis with papillomatosis with hyperpigmentation of the basal layer consistent with Becker's melanosis (not shown).

The patient's treatment was divided into two steps: 1. First minocycline $100 \mathrm{mg} /$ day for three months with $5 \%$ benzoyl peroxide was started; 2. Sequential Laser treatment with five sessions of diode laser for hypertrichosis and 3. Q-switched $694 \mathrm{~nm}$ ruby laser (two sessions) for hyperpigmentation was performed with satisfactory results. The case is presented to show the sequence of treatment in clinical practice.

\section{Discussion}

Becker's melanosis (Becker's nevus or Becker's pigmentary hamartoma) is an acquired, well-demarcated hyperchromic patch often associated with hypertrichosis. It is usually located on the shoulders, anterior chest or scapular region. It is more commonly seen in men (2.5:1) and develops in the peripubertal period, when it

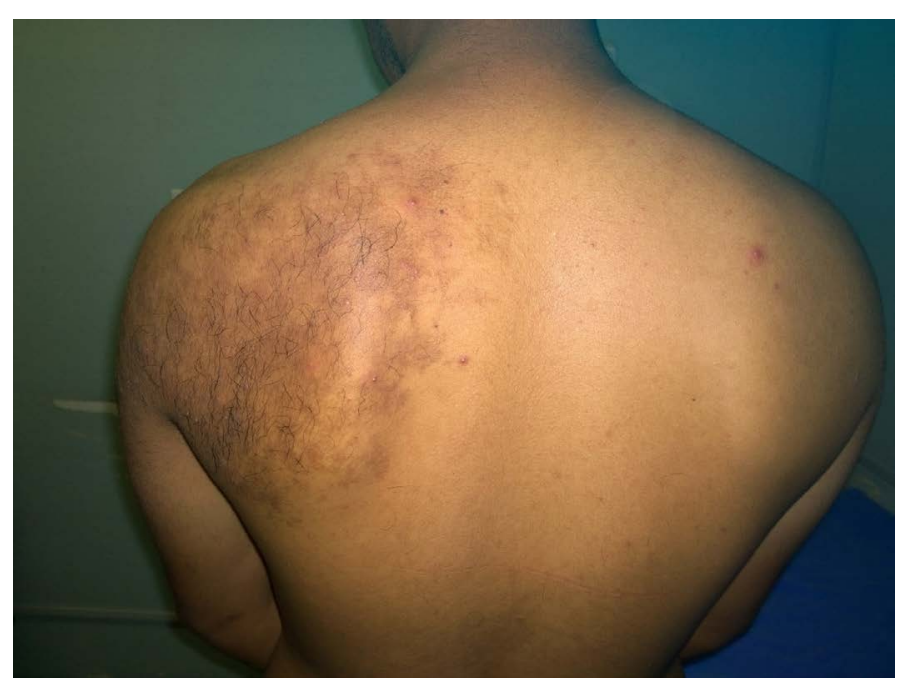

Figure 1. Predilection of acne lesions at the site of the melanosis

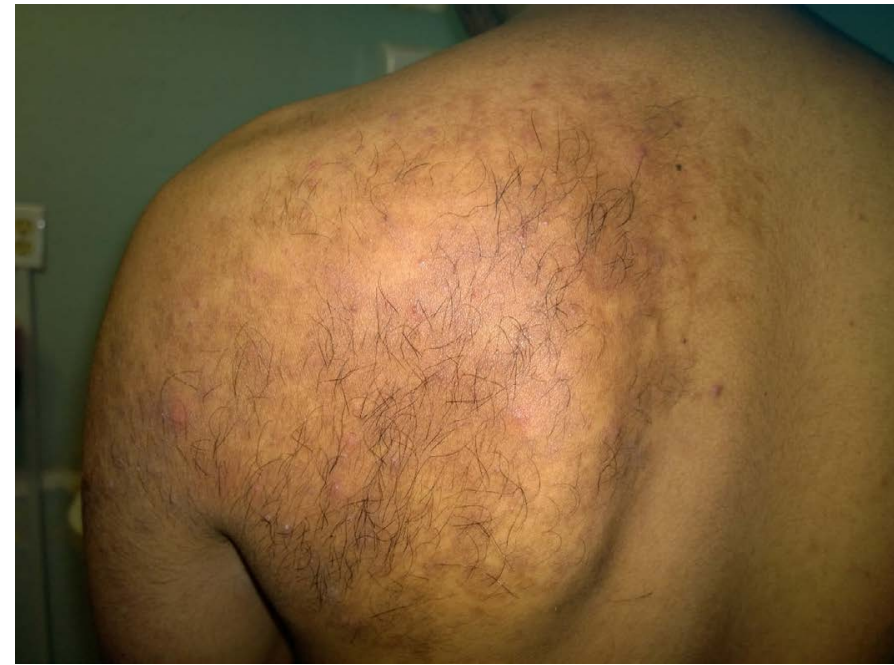

Figure 2. An acquired melanosis with hypertrichosis and acne

increases slowly and irregularly, acquiring a geometric configuration and becoming persistent and asymmetric. Hair density may be variable and may even be absent $[1,2]$.

Its ethiopathogenesis is unknown. Becker's melanosis is considered a hamartoma of ecto-mesodermal tissues appearing sporadically by cutaneous mosaicism. It represents a functional androgen-dependent tumor due to several factors: higher incidence in males, pubertal development, hypertrichosis, association with intralesional acne and anomalous scrotum, in addition to an increased number of androgen receptors and messenger RNA in the site of the lesion [3].

Its evolution is benign; pigmentation stabilizes in one or two years and rarely regresses. Hair growth follows the onset of pigmentation and persists with development of thick hair. It is often associated with breast hypoplasia and other muscle, skin or bone changes ipsilateral to the nevus, which is called Becker's nevus syndrome. Other associated diseases are pityriasis versicolor, and intralesional acne [2]. When these last two associations are presented, their treatment is often preferred prior to laser therapy [4].

*Correspondence to: Andrés Tirado Sánchez, Servicio de Dermatología, Hospital General de México, Dr. Balmis 148, Col. Doctores, Deleg. Cuauhtemoc, México, D.F., C.P. 06726, E-mail: atsdermahgm@gmail.com

Received: August 20, 2018; Accepted: August 28, 2018; Published: August 31, 2018 
Treatment with surgical excision is not an option due to the length of the patch. The patient seeks therapeutic interventions for cosmetic improvement of the hypertrichosis and the hyperpigmentation. Corrective makeup with a variety of water-resistant and light to very opaque products may be a valid adjunctive therapy for patients undergoing long-term treatment or in whom conventional therapy is ineffective $[1,2]$.

The therapeutic approach of Becker's melanosis requires the sequential control of the complications. In the presented case, we oriented the management contrary to the occurrence of complications, therefore, we started with the therapy of acne lesions, later we started treatment of hypertrichosis, and finally the hypermelanosis.

\section{References}

1. Gauglitz G1, Müller DS, Molin S, Ruzicka T, Herzinger T (2013) Becker nevus of the leg with lipoatrophy. JAMA Dermatol 149: 1115-1116. [Crossref]

2. Steiner D, Silva FA, Pessanha AC, Bialeski N, Feola C, et al. (2011) Do you know this syndrome? Becker nevus syndrome. An Bras Dermatol 86: 165-166. [Crossref]

3. Nirdé P, Dereure O, Belon C, Lumbroso S, Guilhou JJ, et al. (1999) The association of Becker nevus with hypersensitivity to androgens. Arch Dermatol 135: 212-214. [Crossref]

4. Lapidoth M, Adatto M, Cohen S, Ben-Amitai D, Halachmi S (2014) Hypertrichosis in Becker's nevus: effective low-fluence laser hair removal. Lasers Med Sci 29: 191-193. [Crossref]

Copyright: (C2018 Tirado-Sánchez A. This is an open-access article distributed under the terms of the Creative Commons Attribution License, which permits unrestricted use, distribution, and reproduction in any medium, provided the original author and source are credited. 